\title{
PENGARUH GAYA KOMUNIKASI, MOTIVASI AKADEMIK, KEBIASAAN MENONTON YOUTUBE TERHADAP SELF EFFICACY AKADEMIK
}

\author{
Mahbub Ahmad ${ }^{1}$, Martani Huseini ${ }^{2}$, Kinkin Yuliaty Subarsa Putri ${ }^{3}$ \\ ${ }^{1}$ STIKOM InterStudi, mahbubachmad2016@gmail.com \\ ${ }^{2}$ Universitas Indonesia, martani0703@yahoo.com \\ ${ }^{3}$ Universitas Negeri Jakarta, kinkinsubarsa@unj.ac.id
}

\begin{abstract}
ABSTRAK
Self Efficacy akademik siswa sangat penting untuk mencapai prestasi akademik. Dampak faktor pendidikan tergantung pada siswa, terutama pada faktor self efficacy akademik siswa dan gaya pembelajaran. Beberapa faktor yang dapat mempengaruhi prestasi akademik siswa seperti gaya komunikasi dosen yang bertujuan untuk mentransmisikan ilmu di kelas. Motivasi akademik juga salah satu faktor yang menentukan berhasil atau tidaknya kegiatan belajar siswa. Sementara itu YouTube menjadi platform yang sukses dalam membuat penyampaian edukatif yang tidak didapatkan oleh pelajar di ruang kelasnya. Tujuan penelitian ini adalah mengkaji peran gaya komunikasi dosen, motivasi akademik, kebiasaan menonton YouTube terhadap self efficacy akademik mahasiswa. Metode penelitian menggunakan pendekatan kuantitatif dan paradigma positivistik. Populasi penelitian ini adalah mahasiswa STIKOM InterStudi. Data diperoleh melalui penyebaran kuesioner secara online dan dianalisis menggunakan SPSS. Hasil penelitian ini menunjukkan bahwa motivasi akademik dan kebiasaan menonton YouTube terbukti memiliki pengaruh positif terhadap self efficacy akademik. Variabel gaya komunikasi dalam penelitian ini ditemukan tidak siginifikan mempengaruhi self efficacy akademik. Hasil penelitian ini juga menunjukkan bahwa secara keseluruhan variabel independen lemah dalam menjelaskan self efficacy akademik mahasiswa STIKOM InterStudi. Penelitian selanjutnya disarankan menambahkan variabel lainnya misalnya karakteristik personal, sikap, kepercayaan kompetensi diri dan lainnya guna mengidentifikasi self efficacy akademik sehingga memperluas hasil temuan manfaat penelitian.
\end{abstract}

Kata Kunci : Gaya Komunikasi, Motivasi Akademik, Kebiasaan Menonton YouTube, Self Efficacy Akademik

\begin{abstract}
Student academic self efficacy is very important to achieve academic achievement. The impact of educational factors depends on students, especially on students' academic self efficacy and learning styles. Several factors can affect student academic achievement such as the communication style of the lecturer which aims to transmit knowledge in the classroom. Academic motivation is also one of the factors that determine the success or failure of student learning activities. Meanwhile, YouTube is a successful platform in making educational delivery that students don't get in their classrooms. The purpose of this study was to examine the role of lecturer communication style, academic motivation, YouTube viewing habits on student academic self efficacy. The research method uses a quantitative approach and a positivistic paradigm. The population of this research is the STIKOM InterStudi students. The data were obtained through online questionnaires and analyzed using SPSS. The results of this study indicate that academic motivation and YouTube viewing habits have a positive effect on academic self efficacy. The variable of communication style in this study was found to have no significant effect on academic self efficacy. The results of this study also indicate that overall the independent variables are weak in explaining the academic self efficacy of the STIKOM InterStudi students. Further research is suggested to add other variables such as personal
\end{abstract}

ISSN: 2355-0287, E-ISSN: 2549-3299

http://ejournal.bsi.ac.id/ejurnal/index.php/jika 
characteristics, attitudes, confidence, self-competence and others to identify academic self efficacy so as to expand the findings of the research benefits.

Keywords: Communication Style, Academic Motivation, YouTube Viewing Habits, Academic Self Efficacy

\section{PENDAHULUAN}

Kemampuan berkomunikasi secara efektif sangat penting bagi dosen atau tenaga pengajar untuk mentransmisikan ilmu yang dimiliki dan membangun interaksi yang baik dengan mahasiswa di kelas. Tenaga pengajar yang kurang memiliki kemampuan dalam berkomunikasi dapat menjadi penyebab kegagalan mahasiswa dalam meningkatkan kemampuan akademiknya (Khan, Khan, ZiaUl-Islam, \& Khan, 2017). Gaya komunikasi dosen atau tenaga pengajar merupakan representasi perilaku yang memberikan kesan tertentu pada mahasiswa (Frumkin \& Murphy, 2007). Kemampuan memahami siswa dan perilaku ramah yang dimiliki oleh dosen juga memiliki dampak positif terhadap peningkatan prestasi akademik mahasiswa (She \& Fisher, 2002). Maka dalam konteks akademik secara luas, kemampuan komunikasi seorang tenaga pengajar merupakan aspek yang penting dalam proses belajar mengajar di kelas (Frumkin \& Murphy, 2007).

Peran dosen juga sangat berpengaruh dalam membangun motivasi belajar siswa, seperti bagaimana dosen menyampaikan materi, metode, dan strategi yang digunakan dalam kegiatan belajar mengajar serta cara berkomunikasi dan berinteraksi dengan siswa; bahkan penampilan dan tingkah laku guru selama mengajar mempengaruhi motivasi belajar siswa (Blašková, Blaško, Jankalová, \& Jankal, 2014).

Gaya belajar konvensional secara umum dilakukan dengan aktivitas tatap muka di kelas, dimana dosen menyampaikan materi pembelajaran kepada mahasiswa dengan keterbatasan waktu penjadwalan (Chawinga, 2017). Gaya komunikasi yang terbatas dengan ruang dan waktu kemudian menjadi berkembang dengan adanya media baru yang juga berkembang saat ini salah satunya adalah media YouTube. Hal ini sesuai dengan dua tantangan yang dihadapi oleh pendidik atau tenaga pengajar di Perguruan Tinggi. Dua tantangan bagi pengajar di Perguruan Tinggi saat ini adalah menjaga materi belajar agar terhubung dengan teknologi yang digunakan oleh siswa saat ini dan membuat materi tersebut menjadi lebih menarik bagi siswa (Lichter, 2012).

Keterbatasan interaksi yang dibatasi ruang kelas kemudian dapat terakomodir dalam media pembelajaran berbasis media sosial dan berbagi video yang melibatkan interaksi tanpa dibatasi ruang dan waktu. Hal ini menjadi peluang besar dan positif guna meningkatkan kegiatan belajar mengajar. Hal ini juga akan memungkinkan terjadinya peningkatan prestasi akademik siswa. Di antara media sosial yang ada, YouTube adalah platform media sosial yang paling sering digunakan dalam pendidikan (Balakrishnan, Liew, \& Pourgholaminejad, 2014). YouTube adalah platform media sosial yang sukses dalam membuat penyampaian edukatif namun tetap bersifat menghibur, hal inilah yang tidak didapatkan oleh pelajar di ruang kelasnya (Hua, 2015). Hal ini menjadi penting bagi pendidik atau tenaga pengajar untuk berupaya dalam mencari dan bahkan mengembangkan konten YouTube yang mampu mendorong siswa dalam kegiatan belajar (Hong, Hwang, Szeto, Tsai, \& Kuo, 2016). Dari hal tersebut, dapat disimpulkan bahwa penting untuk memiliki dan mengembangkan kemampuan tenaga pengajar dalam penguasaan teknologi belajar yang lebih kekinian agar siswa menjadi lebih maksimal dalam belajar dan mencapai hasil berupa prestasi akademik.

Dalam program sarjana, materi akademik menjadi semakin lebih menantang yang kemudian meningkatkan kecemasan siswa terlebih bagi yang memiliki kecemasan sosialterkait dengan penilaian performa atau presentasi mereka di kelas (Topham, P., \& Russell, 2012). Sebuah studi menunjukan bahwa kecemasan sosial dapat berdampak pada perasaan tidak menikmati pembelajaran di sekolah dan juga resiko penarikan diri dari sekolah (Ameringen \& Mancini, 2003). Pada akhirnya kesempatan belajar akan hilang bagi

ISSN: 2355-0287, E-ISSN: 2549-3299 
siswa yang memiliki kecemasan sosial dengan cara menghindari interaksi, baik itu penghindaran secara fisik maupun pnghindaran secara psikologis (Topham, P., \& Russell, 2012). Padahal self efficacy akademik dan kepercayaan diri siswa yang terkait dengan pembelajaran dan performa akademik sangat penting untuk mencapai prestasi akademik yang baik (Zimmerman, 2000). Siswa yang memiliki self efficacy akademik yang tinggi akan mencapai pencapaian yang tinggi pula karena menganggap pembelajaran mereka sebagai tantangan atau tugas yang menarik dan berharga sehingga mereka menerapkan strategi pembelajaran yang masuk akal (Greene, Miller, Crowson, Duke, \& Akey, 2004).

Dampak faktor pendidikan tergantung pada siswa itu sendiri, terutama pada faktor self efficacy akademik siswa dan terkait dengan pemilihan pendekatan yang disukai dalam kegiatan pembelajaran (Verešová, Foglová, Vere, \& Foglová, 2018). Oleh karena itu, maka seorang pendidik harus bertindak untuk meningkatkan self efficacy akademik siswa dan kepercayaan diri siswa karena dengan mekanisme inilah seorang siswa menjadi lebih berhasil dalam pendidikan (Verešová et al., 2018). Pada titik inilah peran seorang pendidik sangat penting dalam mengarahkan dan membentuk siswa yang berhasil.

Oleh karena itu, penelitian ini berupaya untuk mempelajari peran gaya komunikasi, motivasi akademik, dan kebiasaan menonton YouTube terhadap self efficacy akademik mahasiswa STIKOM InterStudi yang dirumuskan dengan pertanyaan seberapa besar pengaruh gaya komunikasi dosen, motivasi akademik dan kebiasaan menonton YouTube terhadap self efficacy akademik mahasiswa STIKOM InterStudi.

\section{KAJIAN LITERATUR \\ Gaya Komunikasi}

Gaya komunikasi adalah himpunan karakateristik ucapan seseorang dalam tindakan komunikasi dan menjadi indikator dari pola seseorang dalam menyampaikan dan mengintepretasi informasi (Pâni, Sandu, Pâni, \& Du, 2015). She dan Fisher (2002) menjabarkan pola komunikasi ke dalam lima indikator yakni komunikasi yang bersifat menantang, komunikasi yang bersifat menyemangati dan memuji, komunikasi yang memberikan dukungan secara non verbal, komunikasi yang bersifat memahami dan bersahabat, dan terakhir adalah komunikasi yang bersifat mengontrol. Hubungan positif ditemukan antara persepsi siswa tentang perilaku komunikasi pengajar mereka dan sikap mereka ketika belajar. Skor prestasi kognitif siswa menjadi lebih tinggi ketika siswa menganggap pengajar mereka menggunakan pertanyaan yang lebih menantang, memberikan lebih banyak dukungan nonverbal, dan lebih memahami juga ramah terhadap siswa (She \& Fisher, 2002).

Sebuah penelitian sebelumnya juga menunjukkan bahwa gaya komunikasi sangat penting diperhatikan oleh dosen atau tenaga pengajar untuk mengurangi kejenuhan belajar, sebagai berikut: mengembangkan gaya komunikasi aktif yang memotivasi, mengembangkan inisiatif secara sosial terhadap lingkungan sekitarnya, mampu menyatakan pendapat dengan mengedepankan jiwa emosional yang terkendali, memberikan informasi dengan penuh perhatian, serta mampu memerintah dengan menunjukkan ketegasan, dan perhatian (Mutawakkil \& Nuraedah, 2019). Perbedaan penelitian tersebut dengan penelitian ini adalah bahwa penelitian ini tidak hanya berfokus pada variabel gaya komunikasi. Pada penelitian ini gaya komunikasi adalah salah satu hal yang mempengaruhi ketercapaian prestasi akademik mahasiswa selain faktor-faktor yang lainnya.

\section{Motivasi Akademik}

Sementara itu, motivasi adalah salah satu dari beberapa faktor yang menentukan berhasil atau tidaknya kegiatan belajar siswa. Salah satu konsep terpenting dalam pendidikan adalah tentang motivasi (Vallerand, R. J., Pelletier, L. G., Blais, M. R., Briere, N. M., Senecal, C., \& Vallieres, 1992). Salah satu sudut pandang yang berguna dalam penelitian motivasi akademik ini adalah bahwa perilaku dapat dimotivasi secara intrinsik, ekstrinsik dan amotivasi (Deci \& Ryan, 1990). Seseorang dapat termotivasi secara intrinsik jika suatu aktivitas dilakukan untuk kesenangan dirinya sendiri yakni sebuah kesenangan yang berasal dari dalam diri sendiri. Perkembangan motivasi intrinsik ini tergantung pada sejauh mana kebutuhan psikologis seseorang yang didukung oleh 
lingkungan sosialnya. Motivasi intrinsik mengacu pada melakukan suatu aktivitas untuk kepuasan inheren dari aktivitas yang dilakukan (Ryan \& Deci, 2000).

Sebaliknya, perilaku yang dimotivasi secara ekstrinsik adalah sesuatu yang berkaitan dengan perilaku yang tidak dilakukan untuk kepentingannya sendiri. Biasanya perilaku tersebut dipengaruhi oleh alasan eksternal. Alasan eksternal ini dapat berupa penghargaan atau hukuman. Seseorang dapat berperilaku karena ingin mendapatkan penghargaan dari orang lain atau perasaan diakui oleh orang lain. Namun seseorang juga dapat berperilaku karena untuk menghindari ancaman hukuman (Ryan \& Deci, 2000). Sementara itu, amotivasi adalah situasi dimana seseorang menganggap perilakunya ditentukan oleh kekuatan eksternal secara penuh dan hal tersebut berada di luar kendalinya sendiri (Cokley, 2000). Dalam sebuah penelitian menunjukkan bahwa motivasi akademik secara intrinsik tidaklah bertentangan dengan motivasi secara ekstrinsik bahkan kedua aspek tersebut justru saling menguatkan satu sama lain dalam pencapaian suatu prestasi (Wilkesmann, Fischer, \& Virgillito, 2015).

Sebaliknya, kesuksesan yang optimal akan sulit tercapai jika tidak adanya motivasi dalam belajar (Hamdu \& Agustina, 2011). Motivasi dapat menjadi indikator penting dari semua faktor yang harus diperhitungkan dalam proses belajar mengajar sehingga perubahan dapat dilakukan untuk meningkatkan apa yang perlu ditingkatkan dan mempertahankan apa yang dilakukan dengan benar, semua ini bertujuan untuk meningkatkan prestasi akademik mahasiswa (Silva, Rodrigues, \& Leal, 2018). Cara dosen atau tenaga pengajar mengajar, materi yang jelas, metode pengajaran yang baik, interaksi yang baik dengan mahasiswa, dan pengelolaan proses perkuliahan juga turut mempengaruhi motivasi akademik mahasiswa. Dosen yang memiliki kinerja, keterampilan, dan sikap yang baik membuat mahasiswa menjadi lebih termotivasi untuk mengikuti perkuliahan, untuk mendengarkan, dan lebih serius dalam belajar (Triyanto, 2019). Dari sini dapat terlihat bahwa dosen atau tenaga pengajar memiliki peranan yang sangat penting dalam membangun motivasi akademik siswa (Agezo, 2010). Selain itu, motivasi juga dapat mempengaruhi performa dalam lingkungan akademik dan performa di antara sesama mahasiswa (Wilkesmann et al., 2015). Sebuah penelitian juga menunjukan bahwa terdapat pengaruh yang signifikan antara motivasi belajar terhadap prestasi akademik siswa kelas 6 SD dalam pelajaran IPA (Hamdu \& Agustina, 2011). Berbeda dengan penelitian yang dilakukan oleh Hamdu dan Agustina adalah bahwa objek penelitian ini dilakukan pada mahasiswa sekolah tinggi.

\section{Kebiasaan Menonton YouTube}

Pada dasarnya, penggunaan teknologi dalam bidang pendidikan merupakan trend saat ini yang membantu proses belajar dan merupakan sesuatu yang tidak dapat dipisahkan dalam kehidupan sehari-hari (Ahmad, 2019). Dalam konteks gaya pembelajaran di era media baru, gaya komunikasi dalam pembelajaran juga sudah berubah menyesuaikan dengan kondisi generasi siswa yang lekat dengan teknologi. Dengan kemajuan teknologi, strategi belajar dan mengajar kini mengalihkan fokusnya pada penggunaan media sosial dengan meningkatkan pengalaman belajar siswa yang bertujuan untuk menciptakan masyarakat yang berbasis pengetahuan (Balakrishnan et al., 2014). Hal ini akan menjadi lebih penting lagi, sebanyak pendekatan pengajaran tradisional yang dianggap sebagai metode paling utama dalam penyampaian satu arah yang tersebar luas di pendidikan tinggi, efektivitasnya harus ditingkatkan dengan memadukannya dengan media sosial (Chawinga, 2017).

YouTube secara pasti telah mengubah perilaku pencarian informasi dan gaya belajar banyak orang (Lai, 2013). Jika banyak orang dahulu mencari informasi melalui buku, koran, majalah, televisi dan radio maka berbeda dengan kondisi sekarang. Banyak orang menggunakan layanan web YouTube dan perangkat canggih lainnya untuk menggantikan kebiasaan menonton televisi ataupun perangkat konvensional lainnya (Pratama, Iqbal, \& Tarigan, 2019).

YouTube sebagai platform untuk tugas belajar memungkinkan siswa untuk memproduksi, mengedit dan menonton hasil video karyanya di ponsel atau laptop di manapun (dengan kemampuan dan ketersediaan Internet) dan kapanpun sehingga kegiatan belajar mengajar dapat dilakukan di luar kelas (Lichter, 2012). 
Hal ini menurut Litcher (2012) akan berdampak besar pada maksimalnya kegiatan di dalam kelas untuk berdiskusi dan berkuliah. Bahkan sebuah studi juga menunjukan bahwa platform media sosial dapat meningkatkan self efficacy akademik siswa dan mengembangkan pembelajaran siswa secara lebih dalam lagi (Tower, Latimer, \& Hewitt, 2014).

\section{Self Efficacy Akademik}

Pada dasarnya semua aspek yang mempengaruhi pembelajaran dan prestasi siswa di kelas idealnya harus menunjang secara positif self efficacy akademik siswa. Bagaimanapun, self efficacy akademik merupakan salah satu komponen dalam motivasi dalam proses pembelajaran siswa (Frith, 2009). Self efficacy akademik siswa menentukan berapa besar upaya yang siswa keluarkan untuk kegiatan belajar dan juga berapa lama mereka akan bertahan dalam kegiatan belajar (Pajares, 1996). Self efficacy akademik adalah hal yang mendominasi motivasi akademik dan prestasi (Zeegers, 2007). Sebuah penelitian di Inggris, menemukan bahwa self efficacy akademik yang tinggi memiliki hubungan positif dengan pendekatan pembelajaran yang sesuai dengan keinginan siswa. Akan tetapi memang self efficacy akademik tidak secara langsung dapat memprediksi pencapaian akademik (Cassidy \& Eachus, 2000). Siswa yang meragukan kemampuan diri mereka sendiri untuk sukses akan menjadi tidak termotivasi untuk belajar (Frith, 2009).

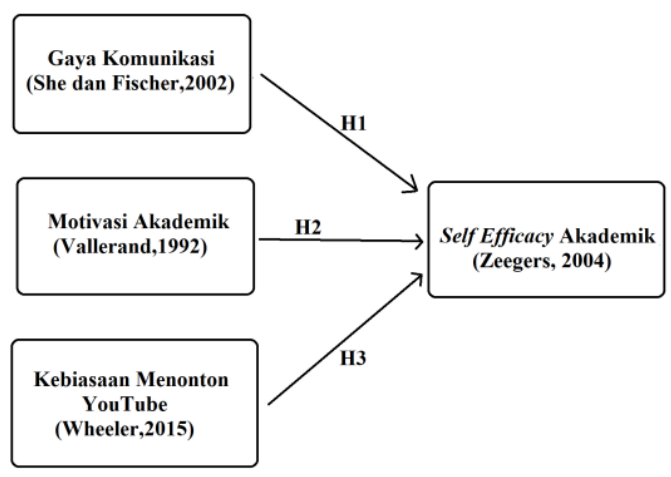

Sumber: Hasil olah data, 2020

Gambar 1. Kerangka Konsep Penelitian

Berdasarkan kerangka konsep penelitian di atas, penelitian ini membahas 4 (empat) variabel dan 3 (tiga) hipotesis. Adapun variabel yang diuji adalah variabel gaya komunikasi, variabel motivasi akademik, variabel kebiasaan menonton YouTube dan variabel self efficacy akademik. Berikut adalah hipotesis dalam penelitian ini;

H1 : Adanya pengaruh Gaya Komunikasi (X1) terhadap Self Efficacy Akademik (Y)

$\mathrm{H} 2$ :Adanya pengaruh Motivasi Akademik (X2) terhadap Self Efficacy Akademik (Y)

H3 : Adanya pengaruh Kebiasaan Menonton YouTube (X3) terhadap Self Efficacy Akademik (Y)

\section{METODE PENELITIAN \\ Paradigma Penelitian}

Paradigma yang digunakan dalam penelitian ini adalah paradigma positivistik. Paradigma positivistik memprediksi pola umum, dan penelitian yang menggunakan paradigma tersebut bersifat obyektif dan dapat digeneralisir (Ollerenshaw \& Creswell, 2002). Temuan fakta-fakta di lapangan diteliti secara objektif dan berdasarkan pada standar-standar tertentu. Penggunaan paradigma positivistik dalam penelitian ini adalah karena penelitian ini ingin mengetahui pengaruh gaya komunikasi dosen, motivasi akademik, kebiasaaan menonton YouTube terhadap self efficacy akademik mahasiswa.

\section{Strategi Penelitian}

Strategi penelitian yang digunakan dalam penelitian ini adalah dengan cara survei online. Survei online menggunakan kuesioner sebagai instrumen pengumpulan data. Survei online ini akan berisikan daftar pertanyaanpertanyaan yang sesuai dengan konteks penelitian. Pemilihan mode online dalam melakukan survei adalah untuk mempermudah pengumpulan data dari mahasiswa. Data survei ini akan dijadikan sebagai data primer dalam penelitian ini.

Penelitian ini menerapkan metode kuantitatif dengan menggunakan kuesioner berbasis selfreported. Kuesioner penelitian ini dibagi menjadi tiga bagian. Bagian pertama pertanyaan terkait informasi profil responden. Bagian kedua terkait informasi perilaku responden terhadap responden behaviour. Bagian ketiga dari kuesioner mengukur item masing-masing variabel penelitian. Variabel Gaya Komunikasi mengadopsi pengukuran dari She dan Fisher (2002) yang membagi menjadi lima indikator dengan skala likert dari 1 (Hampir Tidak Pernah) hingga 5 (Hampir Selalu). Variabel motivasi akademik 
mengadopsi pengukuran dari Vallerand (1992) yang membagi menjadi 28 item pertanyaan dengan skala likert dari 1 (Tidak Setuju) hingga 7 (Sangat Setuju). Variabel YouTube Viewing Habits mengadposi pengukuran dari Wheeler (2015) yang membagi menjadi 5 item pertanyaan dengan skala likert dari 1 (Tidak Setuju) hingga 5 (Sangat Setuju). Sementara itu variabel Academic Self Efficacy mengadopsi pengukuran dari Zeegers (2004) yang membagi menjadi 10 item pertanyaan dengan skala likert 1 (Tidak Setuju) hingga 5 (Sangat Setuju). Semua skala pada variabel disesuaikan dan diterjemahkan sesuai konteks penelitian.

Data yang diperoleh dianalisis dengan univariat dan bivariat. Hasil penelitian akan dijelaskan secara eksplanatif untuk menjelaskan satu generalisasi sampel terhadap populasinya atau menjelaskan hubungan, perbedaan bahkan pengaruh satu variabel dengan variabel lainnya.

Lokasi penelitian dilakukan di STIKOM InterStudi dan objek penelitian adalah mahasiswa aktif STIKOM InterStudi. Sedangkan waktu penelitian dimulai dari April 2020 hingga Mei 2020. Populasi yang akan dijadikan sasaran adalah mahasiswa InterStudi berstatus sebagai mahasiswa aktif yang berjumlah 728 orang. Dalam penelitian ini pengambilan sampel menggunakan rumus Taro Yamane sehingga jumlah responden sejumlah 88 orang yang terdiri dari 57 mahasiswa Penyiaran, 22 mahasiswa Hubungan Masyarakat, 5 mahasiswa Periklanan dan 4 mahasiswa Komunikasi Bisnis

\section{PEMBAHASAN}

\section{Demografi Responden}

Responden dalam penelitian ini adalah mahasiswa STIKOM InterStudi dari konsentras Penyiaran (64,8\%), Hubungan Masyarakat (25,0\%), Periklanan (5,7\%) dan Komunikasi Bisnis (4,5\%) dari angkatan 2013 hingga angkatan 2019. Berdasarkan data tersebut dapat terlihat bahwa mayoritas responden adalah mahasiswa yang mengambil konsentrasi Penyiaran. Sementara itu, mahasiswa yang mengambil konsentrasi Komunikasi Bisnis merupakan responden minoritas.
Tabel 1. Data Demografi Responden

\begin{tabular}{|c|c|c|}
\hline & KETERANGAN & $\mathbf{F}(\%)$ \\
\hline Jenis & Pria & $35(39,8 \%)$ \\
\hline Kelamin & Wanita & $53(60,2 \%)$ \\
\hline \multirow{3}{*}{ Usia } & $18-22$ & $64(72,7 \%)$ \\
\hline & $23-27$ & $22(25,0 \%)$ \\
\hline & $>27$ & $2(2,3 \%)$ \\
\hline \multirow{7}{*}{ Angkatan } & 2013 & $1(1,1 \%)$ \\
\hline & 2014 & $6(6,8 \%)$ \\
\hline & 2015 & $9(10,2 \%)$ \\
\hline & 2016 & $16(18,2 \%)$ \\
\hline & 2017 & $17(19,3 \%)$ \\
\hline & 2018 & $22(25,0 \%)$ \\
\hline & 2019 & $17(19,3 \%)$ \\
\hline \multirow{4}{*}{$\begin{array}{l}\text { Konsen- } \\
\text { trasi }\end{array}$} & Penyiaran & $57(64,8 \%)$ \\
\hline & Humas & $22(25,0 \%)$ \\
\hline & Periklanan & $5(5,7 \%)$ \\
\hline & Komunikasi Bisnis & $4(4,5 \%)$ \\
\hline \multirow{3}{*}{ IPK } & $<3.00$ & $13(14,8 \%)$ \\
\hline & $3.00-3.80$ & $59(67 \%)$ \\
\hline & $>3.80$ & $16(18,2 \%)$ \\
\hline \multirow{4}{*}{$\begin{array}{l}\text { Masa } \\
\text { Studi }\end{array}$} & 1-2 Tahun & $39(44,3 \%)$ \\
\hline & 3-4 Tahun & $33(37,5 \%)$ \\
\hline & 5-6 Tahun & $15(17,1 \%)$ \\
\hline & 7 Tahun & $1(1,1 \%)$ \\
\hline \multirow{5}{*}{$\begin{array}{l}\text { Target } \\
\text { Lulus }\end{array}$} & Tahun 2020 & $28(31,8 \%)$ \\
\hline & Tahun 2021 & $28(31,8 \%)$ \\
\hline & Tahun 2022 & $17(19,4 \%)$ \\
\hline & Tahun 2023 & $11(12,5 \%)$ \\
\hline & Tahun 2024 & $4(4,5 \%)$ \\
\hline \multirow{5}{*}{$\begin{array}{l}\text { Lama } \\
\text { Belajar } \\
\text { per Hari }\end{array}$} & 1-2 Jam & $36(40,9 \%)$ \\
\hline & 3-4 Jam & $25(28,4 \%)$ \\
\hline & 5-6 Jam & $19(21,5 \%)$ \\
\hline & 7-8 Jam & $4(4,6 \%)$ \\
\hline & 9-10 Jam & $4(4,6 \%)$ \\
\hline \multirow{6}{*}{$\begin{array}{l}\text { Frekuensi } \\
\text { Menonton } \\
\text { Youtube } \\
\text { per Hari }\end{array}$} & $1-2$ Kali & $24(27,3 \%)$ \\
\hline & 3-4 Kali & $28(31,8 \%)$ \\
\hline & 5-6 Kali & $10(11,4 \%)$ \\
\hline & 7-8 Kali & $2(2,3 \%)$ \\
\hline & 9-10 Kali & $7(7,9 \%)$ \\
\hline & $>10$ Kali & $17(19,3 \%)$ \\
\hline
\end{tabular}

Sumber: Hasil olah data (2020)

Mayoritas responden mahasiswa adalah mahasiswa yang memiliki masa studi dua tahun (25\%) dengan target lulus adalah di tahun 2020 (31,8\%), $2021 \quad(31,8 \%)$ dan sisanya menargetkan lulus di antara tahun 2022-2024. Rata- rata waktu belajar mahasiswa adalah 3,5 jam per hari dengan persentase terbesar adalah belajar 1 hingga 2 Jam belajar. Dari seluruh responden 
mahasiswa tersebut, yang memiliki IPK kurang dari 3,00 hanya sebesar $14,8 \%$, dan yang memiliki IPK antara 3,0 hingga 3,80 adalah sebesar $67 \%$ sementara itu yang memiliki IPK lebih dari 3,80 adalah sebesar $18,2 \%$. Mayoritas responden mahasiswa juga memiliki kebiasaan menonton YouTube pada kisaran 3 hingga 4 kali sehari $(31,8 \%)$. Sedangkan sebesar $19,3 \%$ responden menonton YouTube lebih dari 10 kali perhari.

\section{Hasil Penelitian}

Hasil model pengukuran menunjukkan bahwa setiap indikator masing-masing variabel memiliki nilai di atas 0,213 ( $\mathrm{R}$ Table) sehingga dapat dipastikan bahwa seluruh indikator telah valid. Sementara itu, Hasil uji reliabilitas menunjukkan bahwa seluruh variabel dalam penelitian telah reliabel ditandai dengan nilai Cronbach Alpha di atas 0,60 (Guilford, 1956) sebagaimana ditunujukkan pada tabel 2.

Tabel 2. Hasil Uji Validitas dan Reliabilitas

\begin{tabular}{lccc} 
Rariabel & RTabel & $\begin{array}{c}\text { Alpha } \\
\text { Cronbach }\end{array}$ & Ket. \\
\hline $\begin{array}{l}\text { Gaya } \\
\text { Komunikasi }\end{array}$ & 0,742 & 0,730 & $\begin{array}{c}\text { Valid \& } \\
\text { Reliabel }\end{array}$ \\
\hline $\begin{array}{l}\text { Motivasi } \\
\text { Akademik }\end{array}$ & 0,716 & 0,918 & $\begin{array}{c}\text { Valid } \\
\text { dan } \\
\text { Reliabel }\end{array}$ \\
\hline $\begin{array}{l}\text { Kebiasaan } \\
\text { Menonton }\end{array}$ & 0,794 & 0,600 & $\begin{array}{c}\text { Valid } \\
\text { dan } \\
\text { YouTube }\end{array}$ \\
$\begin{array}{l}\text { Self } \\
\text { Efficacy } \\
\text { Akademik }\end{array}$ & 0,702 & 0,839 & $\begin{array}{c}\text { Valid } \\
\text { dan } \\
\text { Reliabel }\end{array}$ \\
\hline
\end{tabular}

Sumber: Hasil olah data (2020)

Hasil uji hipotesis penelitian (Tabel 3) dilakukan dengan pengujian nilai t-hitung dan t-tabel untuk mengetahui signifikansi pengaruh masing-masing variabel independen (Gaya Komunikasi, Motivasi Akademik dan Kebiasaan Menonton YouTube) terhadap variabel dependennya (Self Efficacy Akademik). Pada hipotesis pertama ditemukan bahwa variabel gaya komunikasi tidak berpengaruh terhadap variabel self efficacy akademik dengan nilai t-hitung sebesar 0.464 ( $<\mathrm{T}$ table 1,988). Nilai t-hitung tersebut menunjukkan bahwa hipotesis pertama tidak terbukti signifikan (H0 diterima dan Ha Ditolak), maka hipotesis yang menyatakan bahwa variabel gaya komunikasi berpengaruh terhadap variabel self efficacy akademik ditolak.

Pada hipotesis kedua ditemukan bahwa variabel motivasi akademik terbukti signifikan mempengaruhi self efficacy akademik dengan nilai t-hitung sebesar 2.903 ( $>\mathrm{T}$ table 1,988 ) dan nilai koedisien $(\beta)$ sebesar 0.316. Nilai thitung tersebut menunjukkan bahwa $\mathrm{HO}$ ditolak dan Ha diterima, maka hipotesis yang menyatakan bahwa variabel motivasi akademik berpengaruh terhadap variabel self efficacy akademik diterima. Hasil koefisen $(\beta)$ sebesar 0.316 membuktikan bahwa motivasi akademik merupakan variabel yang paling mempengaruhi self efficacy akademik dengan besar pengaruh positif 0.316 dibandingkan dengan variabel lainnya dalam penelitian ini yang memiliki nilai koefisien relatif lebih kecil dibanding variabel ini.

Hipotesis ketiga dalam penelitian ini juga ditemukan signifikan, dimana nilai t-hitung variabel kebiasaan menonton YouTube terhadap self efficacy akademik diketahui sebesar 2.989 (> T table 1,988) dengan nilai koefisien $(\beta)$ sebesar 0.143 . Nilai t-hitung tersebut menunjukkan bahwa $\mathrm{H} 0$ ditolak dan Ha diterima, maka hipotesis yang menyatakan bahwa variabel kebiasaan menonton YouTube berpengaruh terhadap variabel self efficacy akademik diterima. Hasil koefisen ( $\beta$ ) sebesar 0.143 membuktikan bahwa variabel kebiasaan menonton YouTube merupakan variabel kedua yang mempengaruhi self efficacy akademik dengan besar pengaruh positif 0.143 .

\begin{tabular}{cccc}
\multicolumn{4}{c}{ Tabel 3. Hasil Uji Hipotesis } \\
\hline \multirow{3}{*}{ Hipotesis } & $\begin{array}{l}\text { T-Hitung } \\
\text { (>T- } \\
\text { Tabel } \\
\mathbf{1 . 9 8 8})\end{array}$ & $\begin{array}{c}\text { Koefisien } \\
(\boldsymbol{\beta})\end{array}$ & Interpretasi \\
& & \\
\hline
\end{tabular}

H1 Gaya

Komunikasi

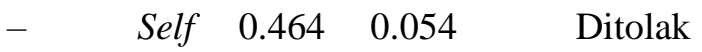

Efficacy

Akademik

$\mathrm{H} 2$

Motivasi

$\begin{array}{llll}\text { Akademik - } & 2.903 & 0.316 & \text { Diterima } \\ \text { Self } & \end{array}$

Efficacy

Akademik

\begin{tabular}{llll}
\hline $\mathrm{H} 3$ & 2.989 & 0.143 & Diterima \\
\hline
\end{tabular}




\begin{tabular}{llcl}
\hline Hipotesis & $\begin{array}{l}\text { T-Hitung } \\
\text { (>T- } \\
\text { Tabel } \\
\mathbf{1 . 9 8 8}\end{array}$ & $\begin{array}{c}\text { Koefisien } \\
(\boldsymbol{\beta})\end{array}$ & Interpretasi \\
\hline Kebiasaan & & & \\
Menonton & & \\
YouTube - & & \\
Self & & \\
Efficacy & & \\
Akademik & & \\
\hline
\end{tabular}

Sumber: Hasil olah data (2020)

Secara keseluruhan variasi pengaruh variabel independen dalam penelitian ini ditunjukkan melalui nilai koefisien determinasi (R2) yang menunjukkan bahwa 21,1\% Self Efficacy Akademik dapat dijelaskan oleh variabel Gaya Komunikasi, Motivasi Akademik dan Kebiasaan Menonton YouTube sedangkan sisanya sebesar $78,9 \%$ dijelaskan oleh variabel-variabel lain di luar penelitian ini.

\section{PENUTUP}

Penelitian ini menunjukkan bahwa motivasi akademik dan kebiasaan menonton YouTube terbukti memiliki pengaruh positif terhadap self efficacy akademik. Motivasi akademik merupakan variabel yang paling dominan mempengaruhi self efficacy akademik. Penelitian ini memiliki kelemahan dimana terdapat satu hipotesis yang tidak signifikan dimana variabel gaya komunikasi tidak ditemukan siginifikan mempengaruhi self efficacy akademik. Hal ini dimungkinkan terjadi karena tidak adanya penetapan sampel penelitian terhadap responden yang representatif, sehingga membuka peluang bagi penelitian selanjutnya untuk dapat menetapkan kriteria terhadap sampel penelitian yang berfokus pada kriteria responden yang memiliki standar self efficacy akademik yang lebih potensial (misal didasarkan pada IPK minimum tertentu). Hasil ini juga berlaku terbatas pada ruang lingkup objek analisis penelitian yaitu mahasiswa STIKOM InterStudi. Temuan yang berbeda dimungkinkan didapatkan apabila dilakukan kajian pada objek analisis yang berbeda.

Hasil penelitian ini juga menunjukkan bahwa variabel gaya komunikasi, motivasi akademik, kebiasaan menonton YouTube sangat lemah dalam menjelaskan self efficacy akademik mahasiswa STIKOM InterStudi (nilai R2 = $21,1 \%$ ). Penelitian selanjutnya disarankan menambahkan variabel lainnya misalnya karakteristik personal, sikap, kepercayaan kompetensi diri dan lainnya guna mengidentifikasi self efficacy akademik sehingga memperluas hasil temuan manfaat penelitian.

\section{REFERENSI}

Agezo, C. K. (2010). Why Teachers Leave Teaching: The Case of Pretertiary Institutions in Ghana. International Journal of Educational Reform, 19(1), 51-69.

Ahmad, N. K. (2019). Tantangan Aplikasi Sekolah Pintar di Kawasan Timur Indonesia. Inter Komunika: Jurnal Komunikasi, 4(1), 44-57.

Ameringen, M. Van, \& Mancini, C. (2003). The impact of anxiety disorders on educational achievement. Journal of Anxiety Disorders, 17, 561-571.

Balakrishnan, V., Liew, T. K., \& Pourgholaminejad, S. (2014). Fun learning with Edooware - A social media enabled tool. Computers \& Education. https://doi.org/10.1016/j.compedu.2014. 08.008

Blašková, M., Blaško, R., Jankalová, M., \& Jankal, R. (2014). Key personality competences of university teacher: comparison of requirements defined by teachers and / versus defined by students. Social and Behavioral Sciences, $\quad 114, \quad 466-475$. https://doi.org/10.1016/j.sbspro.2013.12. 731

Cassidy, S., \& Eachus, P. (2000). Learning Style, Academic Belief Systems, Selfreport Student Proficiency and An International Journal of Experimental. Educational Psychology, (September). https://doi.org/10.1080/713663740

Chawinga, W. D. (2017). Taking social media to a university classroom: teaching and learning using Twitter and blogs. International Journal of Educational Technology in Higher Education. https://doi.org/10.1186/s41239-0170041-6

Cokley, K. O. (2000). Examining the Validity of the Academic Motivation Scale by Comparing Scale Construction to SelfDetermination Theory. Psychological 
Reports, 86(2), 560-564.

Deci, E. L., \& Ryan, R. M. (1990). A Motivational Approach to Self: Integration in Personality. Nebraska Symposium On Motivation, (May 2014).

Frith, C. (2009). Motivation to learn. Educational Communications and Technology, 1-14.

Frumkin, L. A., \& Murphy, A. (2007). Student perceptions of lecturer classroom communication style. European Journal of Social Sciences, 5(3)(October), 45-60.

Greene, B. A., Miller, R. B., Crowson, H. M., Duke, B. L., \& Akey, K. L. (2004). Predicting high school students O cognitive engagement and achievement: Contributions of classroom perceptions and motivation q. Contemporary Educational Psychology, 29, 462-482. https://doi.org/10.1016/j.cedpsych.2004. 01.006

Guilford, J. . (1956). Fundamental Statistics in Psychology and Education (3rd Ed.). New York: McGraw-Hill Book Company.

Hamdu, G., \& Agustina, L. (2011). Pengaruh Motivasi Belajar Siswa Terhadap Pestasi Belajar Ipa Di Sekolah Dasar (Studi Kasus terhadap Siswa Kelas IV SDN Tarumanagara Kecamatan Tawang Kota Tasikmalaya). Jurnal Penelitian Pendidikan, 12(1), 139-147.

Hong, J., Hwang, M., Szeto, E., Tsai, C., \& Kuo, Y. (2016). Internet cognitive failure relevant to self-ef fi cacy , learning interest, and satisfaction with social media learning. Computers in Human Behavior, 55, 214-222. https://doi.org/10.1016/j.chb.2015.09.01 0

Hua, K. (2015). Education as Entertainment: YouTube Sensations Teaching The Future. Retrieved from https://www.forbes.com/sites/karenhua/2 015/06/23/education-as-entertainmentyoutube-sensations-teaching-thefuture/\#5475edfb47c2

Khan, Khan, Zia-Ul-Islam, \& Khan, 2017. (2017). Communication Skills of a Teacher and Its Role in the Development of the Students 'Academic Success. Journal of Education and Practice, 8(1)(January), 18-21.
Lai, K. (2013). How are our undergraduates using YouTube? A survey on music students' use of YouTube and the library's multimedia collection. Library Journal Articles, 16, 199-217. https://doi.org/10.1080/10588167.2013.8 43361.

Lichter, J. (2012). Using YouTube as a Platform for Teaching and Learning Solubility Rules. Journal of Chemical Education, 89(9), 1133-1137.

Mutawakkil, \& Nuraedah. (2019). Gaya Komunikasi Dosen dalam Pembelajaran Mahasiswa. Communicatus: Jurnal Ilmu Komunikasi, 3, 135-152. https://doi.org/10.15575/cjik.v3i2.5765

Ollerenshaw, jo A., \& Creswell, J. W. (2002). Narrative research: A comparison of two restorying data analysis approaches. Qualitative Inquiry. https://doi.org/10.1177/10778004008003 008

Pajares, F. (1996). Self-Efficacy Beliefs in Academic Settings. Review of Educational Research, 66(4), 543-578. https://doi.org/10.3102/00346543066004 543

Pâni, G., Sandu, C., Pâni, I.-O., \& Du, N. (2015). Comparative Study Regarding Communication Styles of The Students. Procedia - Social and Behavioral Sciences, 186, 202-208. https://doi.org/10.1016/j.sbspro.2015.04. 066

Pratama, D. Y., Iqbal, I. M., \& Tarigan, N. A. (2019). Makna Televisi Bagi Generasi Z. Inter Komunika: Jurnal Komunikasi, 4(1), 88-103.

Ryan, R. M., \& Deci, E. L. (2000). SelfDetermination Theory and the Facilitation of Intrinsic Motivation, Social Development, and Well-Being. American Psychologist, 55(1), 68-78.

She, H. C., \& Fisher, D. (2002). Teacher communication behavior and its association with students' cognitive and attitudinal outcomes in science in Taiwan. Journal of Research in Science Teaching, 39(1), 63-78. https://doi.org/10.1002/tea.10009

Silva, R., Rodrigues, R., \& Leal, C. (2018). Academic Motivation Scale: Development , Application and Validation for Portuguese Accounting 
and Marketing Undergraduate Students. International Journal of Business and Management, 13(11), 1-16. https://doi.org/10.5539/ijbm.v13n11p1

Topham, P., \& Russell, G. (2012). Social Anxiety in Higher Education. The Psychologist, 25(4), 280-282.

Tower, M., Latimer, S., \& Hewitt, J. (2014). Social networking as a learning tool: Nursing students' perception of efficacy. Nurse Education Today, 34(6), 10121017.

https://doi.org/10.1016/j.nedt.2013.11.00 6

Triyanto. (2019). The Academic Motivation of Papuan Students in Sebelas Maret University , Indonesia. SAGE Open. https://doi.org/10.1177/21582440188234 49

Vallerand, R. J., Pelletier, L. G., Blais, M. R., Briere, N. M., Senecal, C., \& Vallieres, E. F. (1992). vallerand1992.pdf. Educational and Psychological Measurement, 52(4).

Verešová, M., Foglová, L., Vere, M., \& Foglová, L. (2018). Academic SelfEfficacy, Approach to Learning and Academic Achievement Approach to Learning and Academic Achievement. https://doi.org/10.5772/intechopen.7094 8

Wilkesmann, U., Fischer, H., \& Virgillito, A. (2015). Academic Motivation of Students - The German Case. Discussion Papers Des Zentrums Für HochschulBildung, (May).

Zeegers, P. (2007). Student learning in higher education: a path analysis of academic achievement in science. Higher Education Research and Development, 23(January 2015), 37-41. https://doi.org/10.1080/07294360320001 68487

Zimmerman, B. J. (2000). Self-Efficacy: An Essential Motive to Learn. Contemporary Educational Psychology, 25, 82-91. https://doi.org/10.1006/ceps.1999.1016

BIODATA PENULIS

Mahbub Ahmad adalah seorang mahasiswa program Pascasarjana (Magister Ilmu Komunikasi) di Sekolah Tinggi Ilmu Komunikasi (STIKOM) InterStudi. Penulis juga merupakan lulusan Sarjana Sosiologi dari UNJ dengan jurusan Sosiologi Pembangunan.

Martani Huseini adalah seorang pakar di bidang ilmu administrasi. Beliau mendapatkan gelar Doktor dari Universitas Paris de Sorbonne pada tahun 1983. Terdapat banyak karyanya yang telah terpublikasi antara lain adalah "Menuju Bank yang Ideal dengan Pendekatan Learning Organization", dimuat dalam Jurnal Keuangan \& Perbankan, Penerbit STIE Perbanas, Jakarta, Volume I, No.1 September 1998, "Menata Ulang Strategi Pemasaran Internasional Indonesia", dimuat dalam Jurnal Reformasi Ekonomi, Volume I, No.1, Januari-Maret 2000, dan karya-karya lainnnya.

Kinkin Yuliaty Subarsa Putri adalah seorang Doktor di bidang Ilmu Komunikasi dan juga merupakan seorang Wakil Dekan I Bidang Akademik Fakultas Ilmu Sosial di Universitas Negeri Jakarta (UNJ) 